Abstracta Iranica Abstracta Iranica

Revue bibliographique pour le domaine irano-aryen

Volume 26 | 2005

Comptes rendus des publications de 2003

\title{
«Il sondaggi recenti nel temenos di Hatra ». Topoi 10,1 (2000) [2002], Dossier Hatra, pp. 159-178, 10 figs.
}

\author{
Karin Mosig-Walburg
}

\section{(2) OpenEdition Journals}

Édition électronique

URL : http://journals.openedition.org/abstractairanica/3481

ISSN : 1961-960X

Éditeur :

CNRS (UMR 7528 Mondes iraniens et indiens), Éditions de l'IFRI

Édition imprimée

Date de publication : 15 mai 2005

ISSN : 0240-8910

Référence électronique

Karin Mosig-Walburg, « «Il sondaggi recenti nel temenos di Hatra ». Topoi 10,1 (2000) [2002], Dossier Hatra, pp. 159-178, 10 figs. », Abstracta Iranica [En ligne], Volume 26 | 2005, document 165, mis en ligne le 08 décembre 2005, consulté le 25 septembre 2020. URL : http://journals.openedition.org/ abstractairanica/3481

Ce document a été généré automatiquement le 25 septembre 2020.

Tous droits réservés 
« Il sondaggi recenti nel temenos di Hatra ». Topoi 10,1 (2000) [2002], Dossier Hatra, pp. 159-178, 10 figs.

Karin Mosig-Walburg

Présentation des résultats des sondages entre 1996-2000, en ce qui concerne les phases de colonisation et l'activité de construction à partir du $4^{\mathrm{e}} \mathrm{s}$. av. J.-C.

INDEX

Thèmes : 3.2.3. Séleucides, Parthes et Sassanides

AUTEURS

KARIN MOSIG-WALBURG

Université de Francfort 